\title{
Evaluation of Hematological Parameters in Predicting Short- Term Mortality for COVID-19 Patients with Gastrointestinal Symptoms: A Case-Control Study
}

\author{
Gastrointestinal Semptomları Olan COVID-19 Hastalarında Kısa Süreli \\ Mortaliteyi Öngörmede Hematolojik Parametrelerin Değerlendirilmesi: \\ Bir Vaka Kontrol Çalışması
}

\author{
DSerdar Özdemir1, ¿Abdullah Algın' \\ 'Department of Emergency Medicine, University of Health Sciences Ümraniye Training and Research Hospital, İstanbul, Turkey
}

\begin{abstract}
Introduction: Due to local and systemic pathological mechanisms, laboratory parameters, especially hematological parameters of patients with gastrointestinal symptoms may differ from those without these symptoms. We aimed to investigate the differences between the hematological parameters of COVID-19 patients with and without gastrointestinal symptoms.

Material and Method: Our study was designed as a retrospective case-control study. The case group consisted of COVID-19 patients with confirmed gastrointestinal symptoms, and the control group consisted of those without gastrointestinal symptoms. The hematological parameters of the patients were compared statistically.

Results: In this study, 130 patients were included in the case group and 130 patients in the control group. There was no statistical difference between the groups in terms of the white blood cell count, neutrophil count, lymphocyte count, platelet count, hemoglobin, hematocrit, mean platelet volume, mean corpuscular volume, neutrophil-lymphocyte ratio, platelet-lymphocyte ratio values ( $p$ values: $0.642,0.987,0.132,0.835,0.306,0.430,0.057$, $0.735,0.321$, and 0.031 , respectively).
\end{abstract}

Conclusion: There was no significant difference between the COVID-19 patients with and without gastrointestinal symptoms in the terms of hematological parameters.

Keywords: Case-control study, COVID-19, gastrointestinal symptoms, mortality, SARS-CoV-2
Öz

Giriş: Lokal ve sistemik patolojik mekanizmalar nedeniyle, gastrointestinal semptomları olan hastaların laboratuvar parametreleri -özellikle hematolojik parametreleri olmayanlardan farklı olabilir Çalışmamızda gastrointestinal semptomları olan ve olmayan COVID-19 hastalarının hematolojik parametreleri arasındaki farkı araştırmayı amaçladık.

Gereç ve Yöntem: Çalışmamız retrosfektif vaka kontrol çalışması olarak dizayn edildi. Vaka grubunu doğrulamış gastrointestinal semptomu olan COViD 19 hastaları oluşturdu. Kontrol grubunu ise gastrointestinal semptomu olmayan COViD 19 hastaları oluşturdu. hastaların hematolojik parametreleri istatistiksel olarak karşılaştırıldı.

Bulgular: Vaka grubuna 130 olgu grubuna 130 hasta dahil edildi. gruplar arasında beyaz kan hücresi sayısı, nötrofil sayısı, lenfosit sayısı, trombosit sayısı, hemoglobin, hematokrit, ortalama trombosit hacmi, ortalama korpüsküler hacim, nötrofil-lenfosit oranı, trombosit-lenfosit oranı açısından istatistiksel fark yoktu ( $p$ değerleri 0,642, 0,987, 0,132, $0,835,0,306,0,430,0,057,0,735,0,321,0,031$ sirasiyla)

Sonuç: Gastrointestinal semptomları olan COVID-19 hastaları ile olmayanlar arasında hematolojik parametreler açısından anlamlı bir fark yoktur.

Anahtar Kelimeler: vaka kontrol çalışması, COVID-19, gastrointestinal semptomlar, mortalite, SARS-CoV-2

Corresponding (iletişim): Serdar Özdemir, Department of Emergency Medicine, Health of Sciences University Ümraniye Training and Research Hospital, İstanbul, Turkey

E-mail (E-posta): dr.serdar55@hotmail.com

Received (Geliş Tarihi): 17.07.2021 Accepted (Kabul Tarihi): 24.08.2021 


\section{INTRODUCTION}

Following an unknown pneumonia outbreak in the city of Wuhan, China in December 2019, a new coronavirus was isolated and named severe acute respiratory syndrome coronavirus-2 (SARS-CoV-2) by the International Committee on Taxonomy of Viruses on January 7, 2020. ${ }^{[1]}$ Pneumonia caused by this virus was named Coronavirus Disease 2019 (COVID-19) by the World Health Organization on February $11,2020^{[2]}$ and declared a pandemic on March 11, 2020. The SARS-CoV-2 pandemic has had serious effects not only on the health system but also on economic and social systems around the world. ${ }^{[3]}$

COVID-19 predominantly occurs as a respiratory system infection, and the most common symptoms are fever, fatigue, and dry cough. ${ }^{[4]}$ In addition, various symptoms such as joint and muscle pain, sore throat, nausea, vomiting, diarrhea, conjunctivitis, headache, loss of taste or smell, and skin rash may be observed. ${ }^{[4]}$ Symptoms listed in patients may occur individually or in different combinations. ${ }^{[4]}$ Although SARSCoV-2 is a virus that is mostly effective in the respiratory system, it can also affect the gastrointestinal system and cause gastrointestinal symptoms, such as nausea, vomiting, and diarrhea. ${ }^{[5]}$ The pathogenesis of gastrointestinal symptoms has been discussed in the literature, and several mechanisms have been reported ${ }^{[5]}$ with the primary factors being replication and local inflammatory response in the gastrointestinal mucosa, followed by gastrointestinal response to systemic increased cytokines, gastrointestinal effects of systemic hypoxia, and gastrointestinal microthrombus. ${ }^{[5]}$ We hypothesized that due to these pathological mechanisms, laboratory parameters, especially hematological parameters of patients with gastrointestinal symptoms might differ from those without these symptoms.

In this study, we aimed to investigate the differences between the hematological parameters of COVID-19 patients with and without gastrointestinal symptoms.

\section{MATERIAL AND METHOD}

\section{Study Design}

This retrospective case-control study was conducted at University of Health Sciences Ümraniye Training and Research Hospital, a 686-bed tertiary education hospital with an annual emergency department (ED) census of 453,000. We retrospectively collected the data of patients with corrected COVID-19 who presented to ED between March 01, 2021 and May 01, 2021.

\section{Study Population}

Our study population consisted of COVID-19 patients presenting to ED between March 01, 2021 and May 01, 2021. All patients had a positive reverse transcription polymerase chain reaction (rt-PCR) test for SARS-CoV-2 were included in the study. Patients with missing data were excluded.
The case group consisted of COVID-19 patients with gastrointestinal symptoms, and the control group comprised those without these symptoms. Patients of the same age and gender in the case group were selected from the list of confirmed COVID-19 cases for the control group if possible. If there was no case of the same age and gender, most similar patients were included as controls.

\section{Data Collection}

Demographics, comorbidities, and symptoms, vital parameters at admission, laboratory findings, and ED outcomes were noted from the hospital computer-based patient data system. Comorbidities were noted as coronary artery disease, diabetes mellitus, chronic obstructive pulmonary diseases, hypertension, congestive heart failure, chronic renal failure, and malignancy. Symptoms of the disease were recorded as fever, cough, sputum, dyspnea, weakness, muscle-joint pain, headache, sore throat, vomiting-nausea, and diarrhea. Systolic blood pressure, diastolic blood pressure, pulse pressure, body temperature, respiratory rate, and peripheral oxygen saturation were recorded as vital parameters. The documented laboratory parameters were blood urea nitrogen, creatinine, C-reactive protein, D-dimer, troponin, albumin, white blood cell count, neutrophil count, lymphocyte count, platelet count, mean platelet volume, and mean corpuscular volume. Lastly, the neutrophil-to-lymphocyte ratio and platelet-to-lymphocyte ratio were calculated.

\section{Statistical Analysis}

SPSS version 22.0 for Windows (SPSS Inc, Chicago, IL, USA) was used for statistical analyses. The normality analysis was undertaken using the Kolmogorov-Smirnov test for continuous data. Categorical data were shown with numbers (\%) and compared with the chi-squared test. Quantitative variables were shown with interquartile range (25th-75th percentile) and median values, and then compared between the two groups using Student's t-test or the Mann-Whitney $\mathrm{U}$ test according to the normality of distribution. To identify parameters associated with 30-day mortality, the univariate analysis was conducted using the chi-square, Fisher's exact, Student's $\mathrm{t}$ or Mann-Whitney $\mathrm{U}$ test, where appropriate. To counteract the problem of multiple comparisons, the Bonferroni correction was used. Statistical significance was defined at $\mathrm{p}<0.05$.

\section{Ethics}

Ethical approval for the study was obtained from the Ethics Committee of University of Health Sciences ÜmraniyeTraining and Research Hospital (approval number: 153, date: May 27, 2021). We retrospectively reviewed the data obtained from the computer-based system of the hospital. However, the recorded data did not include any personal identifiable data; it only included clinical information. Therefore, informed consent was waived by the ethics committee. 


\section{RESULTS}

Of the 260 patients included in the study, 130 were included in the case group and 130 in the control group. The mean of age of the case group was $43 \pm 15$ years and that of the control group was $40 \pm 10$ years. A total of seven patients, five in the case group and two in the control group, died within 30 days of ED presentation. The rates of 30-day mortality for the whole study cohort, case group, and control group were $2.7 \%, 3.8 \%$, and $1.5 \%$, respectively. There was no statistically significant difference between the case and control groups in terms of mortality $(p=0.447)$. In the case group, 91 patients were discharged, 35 were hospitalized, and four were admitted to the intensive care unit. In the control group, 103 patients were discharged, 26 were hospitalized, and four were admitted to the intensive care unit. There was no statistically significant difference between the case and control groups in terms of ED outcomes $(p=0.076)$. Table 1 presents the comparison of demographic characteristics, clinical outcomes within the first 24 hours, comorbid diseases, symptoms, vital parameters at presentation, and mortality data between the case and control groups. The comparison of initial laboratory findings between the groups is shown in Table 2. Accordingly, no statistically significant difference was observed between the case and control groups in terms of hematological parameters.

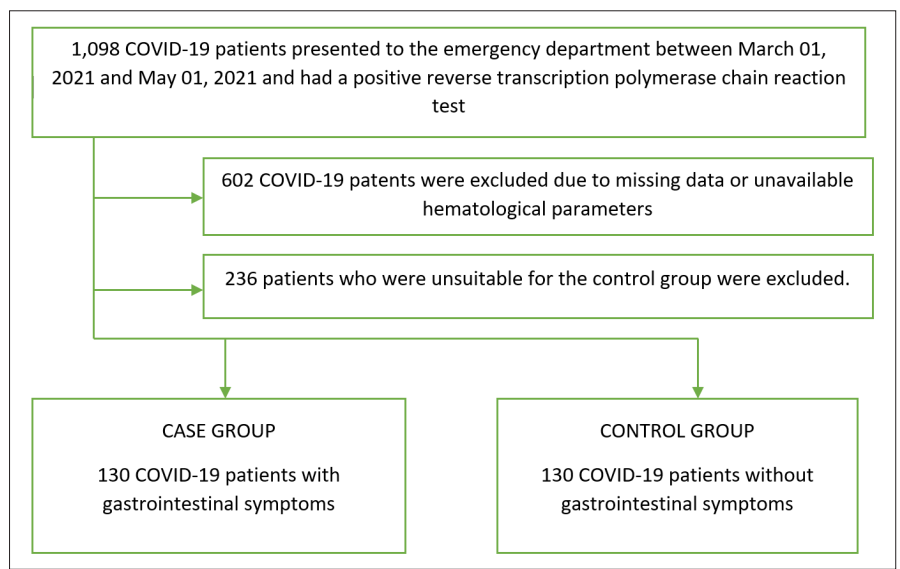

Figure 1. Flowchart of the study Table 1. Baseline characteristics of the enrolled patients and their comparison between the case and control groups

\begin{tabular}{|c|c|c|c|c|}
\hline \multirow[t]{2}{*}{ Variables } & Total & $\begin{array}{c}\text { Case group (with } \\
\text { gastrointestinal symptoms) }\end{array}$ & $\begin{array}{c}\text { Control group (without } \\
\text { gastrointestinal symptoms) }\end{array}$ & \multirow[t]{2}{*}{ p values } \\
\hline & $n=260(\%)$ & $\mathrm{n}=130(\%)$ & $\mathrm{n}=130(\%)$ & \\
\hline Age, years & $41 \pm 12$ & $43 \pm 15$ & $40 \pm 10$ & 0.144 \\
\hline Gender & & & & 0.529 \\
\hline Male & $153(58.8 \%)$ & $74(56.9 \%)$ & $79(60.8 \%)$ & \\
\hline Female & 107 (41.2\%) & $56(43.1 \%)$ & $51(39.2 \%)$ & \\
\hline Clinical outcome within the first 24 hours & & & & 0.076 \\
\hline Discharge & $194(74.6 \%)$ & $91(70 \%)$ & $103(79.2 \%)$ & \\
\hline Admission to inpatient clinics & $61(23.5 \%)$ & $35(26.9 \%)$ & $26(20 \%)$ & \\
\hline Intensive care unit admission & $5(1.9 \%)$ & $4(3.1 \%)$ & $1(0.8 \%)$ & \\
\hline \multicolumn{5}{|l|}{ Comorbidities (+\%/-\%) } \\
\hline Chronic obstructive pulmonary diseases & $7(2.7 \%)$ & $4(3.1 \%)$ & $3(2.3 \%)$ & 0.702 \\
\hline Hypertension & $25(9.6 \%)$ & $19(14.6 \%)$ & $6(4.6 \%)$ & 0.006 \\
\hline Diabetes mellitus & $22(8.5 \%)$ & $16(12.3 \%)$ & $6(4.6 \%)$ & 0.026 \\
\hline Coronary artery disease & $4(1.5 \%)$ & $4(3.1 \%)$ & 0 & 0.122 \\
\hline Congestive heart failure & $3(1.2 \%)$ & $3(2.3 \%)$ & 0 & 0.247 \\
\hline Chronic kidney disease & $4(1.5 \%)$ & $3(2.3 \%)$ & $1(0.8 \%)$ & 0.622 \\
\hline \multicolumn{5}{|l|}{ Frequency of symptoms (n/\%) } \\
\hline Fever & $89(34.2 \%)$ & $43(33.1 \%)$ & $46(35.4 \%)$ & 0.695 \\
\hline Cough & $170(65.4 \%)$ & $84(64.6 \%)$ & $86(66.2 \%)$ & 0.794 \\
\hline Sputum & $6(2.3 \%)$ & $4(3.1 \%)$ & $2(1.5 \%)$ & 0.176 \\
\hline Shortness of breath & $78(30 \%)$ & $44(33.8 \%)$ & $34(26.2 \%)$ & 0.684 \\
\hline Weakness & $47(18.1 \%)$ & $23(17.7 \%)$ & $24(18.5 \%)$ & 0.872 \\
\hline Muscle-joint pain & $34(13.1 \%)$ & $20(15.4 \%)$ & $14(10.8 \%)$ & 0.270 \\
\hline Loss of taste or smell & $13(5 \%)$ & $7(5.4 \%)$ & $6(4.6 \%)$ & 0.776 \\
\hline Headache & $11(4.2 \%)$ & $5(3.8 \%)$ & $6(4.6 \%)$ & 0.758 \\
\hline Sore throat & $29(11.2 \%)$ & $13(10 \%)$ & $16(12.3 \%)$ & 0.555 \\
\hline Nausea-vomiting & $65(25 \%)$ & $65(50 \%)$ & 0 & \\
\hline Diarrhea & $78(30 \%)$ & $78(60 \%)$ & 0 & \\
\hline \multicolumn{5}{|l|}{ Vital parameters } \\
\hline Systolic blood pressure & $123 \pm 17$ & $126 \pm 17$ & $116 \pm 13$ & 0.015 \\
\hline Diastolic blood pressure & $74 \pm 9$ & $75 \pm 10$ & $73 \pm 7$ & 0.372 \\
\hline Pulse pressure & $89 \pm 17$ & $88 \pm 17$ & $89 \pm 17$ & 0.706 \\
\hline Body temperature & $36.5(36.3-37)$ & $36.6(36.4-37)$ & $36.5(36.2-36.8)$ & 0.030 \\
\hline Respiratory rate & $20(16-22)$ & $20(18-22)$ & $18(16-20)$ & 0.143 \\
\hline Oxygen saturation & $97(95-98)$ & $96(94-98)$ & $97(96-98)$ & 0.044 \\
\hline Mortality & $7(2.7 \%)$ & $5(3.8 \%)$ & $2(1.5 \%)$ & 0.447 \\
\hline
\end{tabular}




\begin{tabular}{|c|c|c|c|c|}
\hline \multirow[t]{2}{*}{ Variables } & Total & $\begin{array}{c}\text { Case group (with } \\
\text { gastrointestinal symptoms) }\end{array}$ & $\begin{array}{l}\text { Control group (without } \\
\text { gastrointestinal symptoms) }\end{array}$ & p values \\
\hline & $\mathrm{n}=2012(\%)$ & $n=1971(\%)$ & $n=41(\%)$ & \\
\hline Glucose, mg/dL & $102(91-117)$ & $106(94-119)$ & $99(89-109)$ & 0.027 \\
\hline Blood urea nitrogen, $\mathrm{mg} / \mathrm{dL}$ & $25.68(12.84-29.96)$ & $25.68(17.12-29.96)$ & $23.54(3.21-29.96)$ & 0.190 \\
\hline Creatinine, mg/dL & $0.82(0.68-0.95)$ & $0.88(0.72-0.95)$ & $0.79(0.68-0.94)$ & 0.311 \\
\hline Albumin, g/dL & $4.27(3.94-4.57)$ & $4.19(3.91-4.44)$ & $4.42(4.11-4.68)$ & 0.044 \\
\hline Alanine aminotransferase, IU/L & $22(15-35)$ & $23(16-37)$ & $19(13-33)$ & 0.315 \\
\hline Aspartate aminotransferase, IU/L & $23(18-32)$ & $23(18-33)$ & $23(17-28)$ & 0.115 \\
\hline Sodium mg/L & $139(137-140)$ & $139(137-140)$ & $139(137-140)$ & 0.346 \\
\hline Potassium mg/L & $4.1(3.7-4.4)$ & $4.1(3.7-4.4)$ & $3.9(3.7-4.3)$ & 0.236 \\
\hline D-dimer, mg/L & $82(42-2613.8)$ & $131.5(52.5-3642.9)$ & $57(32.5-2089.35)$ & 0.022 \\
\hline Troponin (cTnl), ng/mL & $0.02(0.01-0.05)$ & $0.03(0.01-0.06)$ & $0.01(0.01-0.03)$ & 0.005 \\
\hline C-reactive protein, mg/L & $0.3(0.2-1.4)$ & $0.4(0.2-1.6)$ & $0.2(0.2-0.8)$ & 0.039 \\
\hline \multicolumn{5}{|l|}{ Hematological test parameters } \\
\hline White blood cell count & $7.07 \pm 3.33$ & $7.17 \pm 3.33$ & $6.97 \pm 3.34$ & 0.642 \\
\hline Neutrophil count & $4.62 \pm 2.62$ & $4.61 \pm 2.56$ & $4.62 \pm 2.70$ & 0.987 \\
\hline Lymphocyte count & $1.88 \pm 1.16$ & $1.78 \pm 1.17$ & $2 \pm 1.14$ & 0.132 \\
\hline Platelet count & $234.74 \pm 64.28$ & $233.91 \pm 64.58$ & $235.61 \pm 64.23$ & 0.835 \\
\hline Hemoglobin count & $13.9(12.6-15.3)$ & $14.1(12.8-15.3)$ & $13.8(12.3-15.3)$ & 0.306 \\
\hline Hematocrit count & $37.63 \pm 12.62$ & $38.25 \pm 11.81$ & $36.98 \pm 13.43$ & 0.430 \\
\hline Mean platelet volume & $9.5(8.7-10.2)$ & $9.4(8.6-10.2)$ & $9.5(8.9-10.1)$ & 0.057 \\
\hline Mean corpuscular volume & $85.5(82.1-88.5)$ & $85.5(80.8-88.6)$ & $85.5(82.4-88.5)$ & 0.735 \\
\hline Neutrophil-to-lymphocyte ratio & $2.23(1.47-4.45)$ & $2.44(1.49-4.72)$ & $2.02(1.43-3.94)$ & 0.321 \\
\hline Platelet-to-lymphocyte ratio & $125.99(93.51-187.85)$ & $140.34(97.27-193.06)$ & $115.36(89.46-170.59)$ & 0.031 \\
\hline
\end{tabular}

\section{DISCUSSION}

In this study, we examined the differences between the hematological parameters of COVID-19 patients presenting to ED with and without gastrointestinal symptoms. We found no significant difference between these two groups in terms of hematological parameters. To the best of our knowledge, this is the first study that investigated whether hematological parameters differed according to the presence or absence of gastrointestinal symptoms among COVID-19 cases.

In the literature, since SARS-CoV-2 RNA was first detected in the stool of a COVID-19 case with symptoms of nausea, vomiting, and diarrhea in the USA, more attention has been paid to the gastrointestinal system. ${ }^{[6]}$ Digestive symptoms, such as anorexia, nausea, vomiting, and diarrhea are frequently reported in COVID-19 patients. ${ }^{[7]}$ In addition, gastrointestinal symptoms, although rare, may be the only manifestation of the SARS-CoV-2 infection.$^{[8]}$ In support of this, the COVID-19 disease was reported in a patient with a positive stool test but negative pharyngeal and sputum viral tests..$^{[9]}$ In a multicenter study in China involving 1,099 patients of the same age, 55 $(5 \%)$ of the COVID-19 patients were reported to have nausea or vomiting and $42(3.8 \%)$ had diarrhea. ${ }^{[7]}$ Diarrhea induced by SARS-CoV-2 was the initial symptom in a patient with COVID-19. ${ }^{[8]}$ Diarrhea is also a common gastrointestinal symptom in patients with COVID-19, with an incidence ranging from $1.3 \%$ to $29.3 \%$ in the literature. ${ }^{[10]}$ However, the frequency of gastrointestinal symptoms differs between studies, ${ }^{[6,7]}$ which may be related to the different criteria used in the definition of diarrhea. Another plausible explanation may be clinicians' reluctance or disregard in relation to reporting gastrointestinal symptoms in COVID-19 patients. ${ }^{[1]}$

Hoffmann et al. ${ }^{[1]]}$ suggested that the gastrointestinal system infection mechanism of SARS-CoV was the angiotensinconverting enzyme-2 (ACE-2) cell receptor. SARS-CoV-2 uses ACE2 as a cell entry receptor. ${ }^{[12]}$ Xiao et al. ${ }^{[13]}$ showed that ACE-2 was rarely expressed in the esophageal epithelium but abundantly distributed in gastric, duodenal, and rectum glandular epithelial cells in the staining of viral nucleocapsid protein according to the analysis of endoscopic biopsy samples. That study showed that the gastrointestinal infection of SARS-CoV-2 and infectious virions could be secreted from virus-infected digestive tract cells. ${ }^{[13]}$ Another study conducted by Liang et al. ${ }^{[10]}$ reported that ACE-2 was highly expressed in the small intestine, especially in proximal and distal enterocytes. In their in vitro experimental study, Lamer et al. ${ }^{[14]}$ successfully grew the virus in test tubes using the cell culture models of the human intestine. The authors showed how the virus replicated itself and damaged intestinal cells. ${ }^{[14]}$ Lamer et al. ${ }^{[14]}$ reported that the interaction between SARS-CoV-2 and ACE-2 could disrupt the function of ACE-2, resulting in diarrhea. Many researchers argue that fecal-oral transmission may be possible considering that SARS-CoV-2 RNA is detected in the stool and replicated in the gastrointestinal tract in some COVID-19 cases. $^{[15]}$

Several mechanisms have been described in the literature for the occurrence of gastrointestinal symptoms. Firstly, viremia damages the gastrointestinal tract indirectly or directly through an inflammatory response. The chain 
reaction of inflammatory factors and viremia can damage the gastrointestinal tract. ${ }^{[16]}$ This systemic mechanism of action is considered to be especially effective in the patient group in which fecal viral replication cannot be demonstrated. [16] Secondly, enteropathic viruses can directly damage the intestinal mucosa and cause digestive symptoms. ${ }^{[14]}$ This mechanism may be more effective in the patient group with known viral replication in the stool. ${ }^{[14]}$ As a third mechanism, the gastrointestinal flora affected by the virus may be effective in the development of gastrointestinal symptoms; however, more evidence is needed to prove this idea. ${ }^{[17]}$ It has been reported that mechanisms such as systemic hypoxia and gastrointestinal microthrombosis may also be additionally effective in critically ill COVID-19 patients. In our study, we hypothesized that hematological markers might be affected differently in this clinical entity, which has systemic and local effects. However, we found that hematological parameters were affected similarly in both COVID-19 groups with and without gastrointestinal symptoms. A logical explanation for this may be that systemic rather than local effects are predominant in patients with gastrointestinal symptoms.

\section{Limitations}

There are several limitations to our study, with the most important being the retrospective design and data being obtained from the hospital's computer-based information system. In addition, not all patients with COVID-19 were routinely tested for hematological parameters, and we had to exclude 602 COVID-19 cases due to the lack of data on hematological parameters. Furthermore, similar to other studies investigating gastrointestinal symptoms in COVID-19 patients, there may have been possible data loss or erroneous data because clinicians underestimated gastrointestinal symptoms. Finally, the single-center and limited cohort of our study limits the generalizability of our results; therefore, our data should be validated by further multicenter studies with larger cohorts.

\section{CONCLUSION}

According to our findings, there is no significant difference between the COVID-19 patients with and without gastrointestinal symptoms in terms of hematological parameters. The results of this study should be confirmed by further multicenter studies.

\section{ETHICAL DECLARATIONS}

Ethics Commite Approval: Ethical approval for the study was obtained from the Ethics Committee of University of Health Sciences Ümraniye Training and Research Hospital (approval number: 153, date: May 27, 2021).

Informed Consent: Because the study was designed retrospectively, no written informed consent form was obtained from patients.

Referee Evaluation Process: Externally peer-reviewed.
Conflict of Interest Statement: The authors have no conflicts of interest to declare.

Financial Disclosure: The authors declared that this study has received no financial support.

Author Contributions: All of the authors declare that they have all participated in the design, execution, and analysis of the paper, and that they have approved the final version.

\section{REFERENCES}

1. Pal M, Berhanu G, Desalegn C, Kandi V. Severe Acute Respiratory Syndrome Coronavirus-2 (SARS-CoV-2):An Update. Cureus 2020;12(3):e7423.

2. Eroglu SE, Aksel G, Altunok I, et al. Can Google ${ }^{\circledR}$ trends predict emergency department admissions in pandemic periods? Med Sci 2021;10(1):111-7.

3. Sert E, Mutlu H, Kokulu K, Sarıtaş A. Anxiety Levels and Associated Factors Among Emergency Department Personnel Fighting COVID-19. J Contemp Med. 2020;10(4):556-61.

4. Galanopoulos M, Gkeros F, Doukatas A, et al. COVID-19 pandemic:Pathophysiology and manifestations from the gastrointestinal tract. World J Gastroenterol. 2020;26(31):4579-88.

5. Holshue ML, DeBolt C, Lindquist S, et al. First case of 2019 novel coronavirus in the United States. N Engl J Med. 2020;382:929-36.

6. Guan WJ, Ni ZY, Hu Y, et al. Clinical characteristics of coronavirus disease 2019 in China. N Engl J Med. 2020;382:1708-20.

7. Song Y, Liu P, Shi XL, et al. SARS-CoV-2 induced diarrhea as onset symptom in patient with COVID-19. Gut. 2020;69(6):1143-4.

8. Chen L, Luo JH, Bai Y, Wang M. COVID-19 disease with positive fecal and negative pharyngeal and sputum viral tests. Am J Gastroenterol. 2020;115(5):790

9. Lee $C$, Huo T, Huang Y. Gastrointestinal and liver manifestations in patients with COVID-19. J Chin Med Assoc. 2020;83(6):521-3.

10. Liang W, Feng Z, Rao S, et al. Diarrhea may be underestimated:a missing link in 2019 novel coronavirus. Gut. 2020;69(6):1141-3.

11. Hoffmann M, Kleine-Weber $H$, Schroeder $S$, et al. SARSCoV-2 cell entry depends on ACE2 and TMPRSS2 and is blocked by a clinically proven protease inhibitor. Cell. 2020;181(2):271-80.

12. Wan Y, Shang J, Graham R, Baric RS, Li F. Receptor recognition by the novel coronavirus from Wuhan:an analysis based on decade-long structural studies of SARS coronavirus. J Virol. 2020;94(7):e00127-20.

13. Xiao F, Tang M, Zheng X, Liu Y, Li X, Shan H. Evidence for Gastrointestinal Infection of SARS-CoV-2. Gastroenterology. 2020;158(6):1831-3.

14. Lamers MM, Beumer J, van der Vaart J, et al. SARS-CoV-2 productively infects human gut enterocytes. Science. 2020;369(6499):50-4.

15. Guo M, Tao W, Flavell RA, Zhu S. Potential intestinal infection and faecal-oral transmission of SARS-CoV-2. Nat Rev Gastroenterol Hepatol. 2021;18(4):269-83.

16. Cao TT, Zhang GQ, Pellegrini E, et al. COVID-19 and its effects on the digestive system. World J Gastroenterol. 2021;27(24):3502-15.

17. Zuo T, Liu Q, Zhang F, et al. Depicting SARS-CoV-2 faecal viral activity in association with gut microbiota composition in patients with COVID-19. Gut. $2021 ; 70(2): 276-84$. 